\title{
The use of distance learning technologies in preparing students (future biology teachers)
}

\section{O uso de tecnologias de ensino a distância na preparação de alunos (futuros professores de biologia)}

\section{El uso de tecnologías de aprendizaje a distancia en la preparación de estudiantes (futuros profesores de biología)}

\author{
Halyna Biletska $^{1}$ iD , Nataliia Mironova ${ }^{1}$ iD Natalia Kazanishena $^{2}$ iD , Serhii Skrypnyk $^{1}$ iD \\ ${ }^{1}$ Khmelnytskyi National University, Khmelnytskyi, Ukraine. \\ ${ }^{2}$ Kamianets-Podilskyi Ivan Ohiienko National University, Kamianets-Podilskyi, Ukraine. \\ Corresponding author: \\ Halyna Biletska \\ Email: rushcyshyn_m@ukr.net
}

\begin{abstract}
How to cite: Biletska, H., Mironova, N., Kazanishena, N., \& Skrypnyk, S. (2022). The use of distance learning technologies in preparing students (future biology teachers). Revista Tempos e Espaços em Educação, 15(34), e16908. http://dx.doi.org/10.20952/revtee.v15i34.16908
\end{abstract}

\begin{abstract}
The current stage in the development of pedagogical education in the world is characterized by a special intensity and scale of transformations due not only to the urgent tasks of forming a young personality, but also to the involvement of the education system in the world integration processes taking place in the context of informatization and globalization. The purposeful acquisition of knowledge, skills and abilities by future biology teachers, an orientation towards the development, development and implementation of effective mechanisms for its formation is an important component of education. The global educational community is faced in 2020 with a global challenge caused by the pandemic caused by the spread of the SARS-CoV-2 coronavirus. The governments of most countries were not ready for such a large-scale pandemic; their practical measures were formed on a situational basis. To counter the spread of COVID-19, educational institutions have been temporarily closed almost all over the world. The purpose of the article is to study the features of the implementation of the distance education system in the process of teaching students - future biology teachers, including the study of the main advantages and disadvantages of this process. For this, the methods of theoretical research of specialized literature were used.
\end{abstract}

Keywords: COVID-19 pandemic. Distance education system. Future biology teachers. Pedagogical education. Pedagogy. 


\section{RESUMO}

O atual estágio de desenvolvimento da educação pedagógica no mundo é caracterizado por uma especial intensidade e escala de transformações devidas não só às tarefas urgentes de formação de uma personalidade jovem, mas também ao envolvimento do sistema educacional nos processos de integração mundial que se estendem. lugar no contexto da informatização e da globalização. $A$ aquisição proposital de conhecimentos, aptidões e aptidões por parte dos futuros professores de biologia, uma orientação para o desenvolvimento, desenvolvimento e implementação de mecanismos eficazes para a sua formação é uma componente importante da educação. A comunidade educacional global se depara em 2020 com um desafio global causado pela pandemia causada pela disseminação do coronavírus SARS-CoV-2. Os governos da maioria dos países não estavam prontos para uma pandemia em tão grande escala; suas medidas práticas foram formadas em uma base situacional. Para conter a disseminação do COVID-19, instituições educacionais foram temporariamente fechadas em quase todo o mundo. O objetivo do artigo é estudar as características da implantação do sistema de educação a distância no processo de ensino de alunos - futuros professores de biologia, incluindo o estudo das principais vantagens e desvantagens desse processo. Para isso, foram utilizados os métodos de pesquisa teórica da literatura especializada.

Palavras-chave: Educação pedagógica. Futuros professores de biologia. Pandemia COVID-19. Pedagogia. Sistema de educação a distância.

\section{RESUMEN}

La etapa actual en el desarrollo de la educación pedagógica en el mundo se caracteriza por una especial intensidad y escala de transformaciones debidas no solo a las urgentes tareas de formar una personalidad joven, sino también a la implicación del sistema educativo en los procesos de integración mundial asumiendo lugar en el contexto de la informatización y la globalización. La adquisición intencionada de conocimientos, habilidades y habilidades por parte de los futuros profesores de biología, una orientación hacia el desarrollo, desarrollo e implementación de mecanismos efectivos para su formación es un componente importante de la educación. La comunidad educativa mundial se enfrenta en 2020 a un desafío mundial causado por la pandemia causada por la propagación del coronavirus SARS-CoV-2. Los gobiernos de la mayoría de los países no estaban preparados para una pandemia de tan gran escala; sus medidas prácticas se formaron sobre una base situacional. Para contrarrestar la propagación del COVID-19, las instituciones educativas se han cerrado temporalmente en casi todo el mundo. El propósito del artículo es estudiar las características de la implementación del sistema de educación a distancia en el proceso de enseñanza a los estudiantes - futuros profesores de biología, incluyendo el estudio de las principales ventajas y desventajas de este proceso. Para ello, se utilizaron los métodos de investigación teórica de la literatura especializada.

Palabras clave: Educación pedagógica. Futuros profesores de biologia. Pandemia de COVID-19. Pedagogía. Sistema de educación a distancia.

\section{INTRODUCTION}

The coronavirus pandemic has affected all spheres of public life without exception. The forced suspension of a number of industries, a significant decline in business and investment activity, the cessation of international traffic and face-to-face international contacts demonstrated the seriousness of the situation. The education sector was one of the first to feel the impact of the coronavirus epidemic and responded to the restrictions by transferring all educational activities to a distance mode.

The rapid transfer of many processes to the network has caused the need for an early response to new changing conditions on the part of government bodies, relevant ministries and universities themselves. The changes that took place affected not only teaching methods, but also 
the very approach to teaching, the formation of competencies among students, the organization of the educational process, which caused an ambiguous reaction among the participants in the educational process.

The extreme transition of higher education to distance learning in the context of a pandemic has created a unique situation in which it was distance technologies that turned out to be the only possible ones to be used in the current circumstances. The features of this transition are actively discussed today and are reflected in a variety of analytical works and expert opinions (Awe, Church, 2020).

The topics actively discussed in the scientific community in this context are currently the modern transformations of higher education, the role of digital technologies in new teaching practices, and solving the problems caused by distance education in a pandemic. Increased attention is paid to the adaptation of the teaching staff to the extreme transition to digital services and remote platforms.

In general, it can be noted that the transition of universities to remote mode during a pandemic has become the most discussed topic at the moment, especially given the difficult epidemiological situation in the world.

The modern information society is developing at a rapid pace, which means that there is a need to form a competent personality capable of actively participating in the development of education, science and culture. Today, the tasks of creating favorable conditions for identifying and developing the abilities of students, the development of their educational and cognitive activity are put forward to the fore in general educational institutions. As a result, in the process of professional training of future teachers of informatics, it is necessary to form subject knowledge and skills, but also to promote the development of those personal qualities of graduates that would allow them to solve new pedagogical problems in the future and reproduce new approaches to the process of general education (Beyth-Marom, Chajut, Roccas, Sagiv, 2003).

Future teachers should prepare and present educational material, taking into account modern approaches to teaching, apply information and communication technologies in the educational process, namely, it is advisable to use educational tools posted on the Internet.

With the rapid development of technologies, the key competencies of the individual are the ability to learn, operate and manage information, therefore, it is necessary to focus on activity and developmental technologies in the educational process. The emergence and development of distance learning technologies occurs along with traditional ones, the use of the former allows teaching and learning individually, regardless of place and time. All over the world, there is an increase in the number of students studying in distance technologies, and an increase in the number of universities using distance technologies in the educational process (Fedorov, Mialkina, Sedykh, Zhitkova, 2021).

Teachers must constantly improve themselves, learn throughout life, raise the level of professional competence, and be creative in their professional activities.

The manifold increase in information flows forces us to formulate fundamentally new priorities in the training of future teachers of informatics. Higher educational institutions are faced with the task of forming a normative and motivational-value structure of the personality of a future specialist, the main component of which will be the need for constant self-improvement.

Currently, there are several distance learning technologies. In education, they differ (Harunasari, Halim, 2019):

- in the form of presentation of educational materials;

- by the presence of an intermediary in the training system with the degree of use of telecommunications and personal computers;

- on technologies for organizing control of the educational process; 
- according to the degree of application in teaching technology of the usual methods of conducting the educational process;

- on the methods of student identification when passing exams.

The main purpose of using distance learning technologies in higher educational institutions is to provide students with access to electronic educational resources through the use of modern information technologies and telecommunication networks.

This technology is characterized by a strong cognitive motivation created by the Internet and the quality of specialist training. This is what makes distance learning a learning technology for the 21st century.

It is precisely the increased motivation that makes distance learning different from distance learning, and a qualitative leap is associated with this, as a result of which it cannot be called a new stage in the development of distance learning.

The main features of distance learning are high professionalism, desire for cooperation, selfaffirmation and a high level of communication with colleagues. Distance learning is characterized by a sharp increase in socially significant motives (Kassabolat et al, 2020):

- business;

- cognitive;

- cooperation;

- self-realization and development;

- self-affirmation and communication;

- due to the use of open and computer learning and modern means of communication.

The characteristic features of distance learning include: flexibility, modularity, parallelism, large audience, economy, manufacturability, social equality, internationality, a new teacher's role, a positive impact on the student, quality.

Distance learning technologies in higher education reveal the possibilities of positively influencing the solution of the following problems in the training of future biology teachers:

-increasing the level of quality of education in universities;

-implementation of the needs of future specialists in educational services;

-increasing professional mobility and activity of future specialists;

-forming a single educational space within the framework of higher education;

-individualization of education in the case of mass higher education.

Distance learning technologies include an individualized process of transferring and assimilating knowledge, abilities, skills and methods of cognitive activity of future specialists. Such technologies can be seen as a natural stage in the evolution of the traditional education system from a blackboard with chalk to an electronic board and computer learning systems, from a library to an electronic one, from a regular classroom to a virtual classroom.

Such technologies enable distance learning via the Internet; to diversify the means of communication between students and teachers (e-mail, chat, forum, file exchange, etc.); activate the role of the teacher and exercise full control over the learning process; apply a multilevel testing system; replenish the database, accumulate versatile statistics.

The use of distance technologies in the learning process allows students to choose a convenient time for studying and mastering academic disciplines, independently carry out remotely - modular control and analysis of their educational activities, and teachers - systematically manage the educational work of students, monitor and analyze their activities for each module of the academic discipline. stimulating the student to qualitatively master the content of higher education.

\section{METHODOLOGY}

The purpose of the article is to study the features of the implementation of the distance education system in the process of teaching students - future biology teachers, including the study 
of the main advantages and disadvantages of this process. For this, a number of methods were applied, which form the research methodology. The study was carried out using the following theoretical methods: systems analysis and synthesis, induction and deduction, comparison, classification, generalization and systematization, idealization and abstraction.

\section{RESULTS AND DISCUSSION}

The widespread adoption of online education today is directly related to the COVID-19 pandemic. Vaccines and related medications give hope that humanity will reduce the danger of coronavirus infection to the level of problems of known viruses. The world will return to normal life. But, most likely, it will be a different life.

To understand the "new normality" in general and in relation to education in particular is an urgent philosophical task. With regard to the near post-view future, there is every reason to believe that the fundamental characteristic of traditional full-time education will be the real interaction of online and offline forms of education. A clear indication of this is the rapidity of the recent transition to online learning. The latter is supported by the quantitative dissemination and qualitative development of information and communication devices and technologies. Here, through the development of virtual reality technologies, it is planned to mitigate the severity of known problems, for example, the inability to ensure the participation of students in real laboratory work. In accordance with this, the form of a modern balanced philosophy of online education is set. The initial condition for the existence of this philosophy is to take into account all the achievements and advantages of traditional full-time education. But we need to develop all the strengths of online education as a real competitor to offline education (Fedorov, Mialkina, Sedykh, Zhitkova, 2021).

One of the central objects of online education is the monitor screen - a direct tool for educational communication between teachers and students and students with each other. The difficulties that arise here and the opportunities that open up largely determine the quality of online education. There are positive prospects for building educational online communication between students. Any interesting educational problem can be organized so that everyone in the study group, divided into pairs, conducts full-fledged online disputes on it, and then they themselves, based on certain criteria (after watching the relevant video materials), determine the winners.

By analogy, one can come up with a number of similar methods of educational work - for example, so that some of the new educational topics are taught to each other by students online, followed by the determination of the best ones. Individual educational online communication, in principle, is not much different from the traditional one. But big problems arise when you have to communicate with a large audience - for example, read an online lecture to a large stream - since today there is no reliable way to check the level of attention, interest in the material presented (which is quite easy to determine offline). Suppose that the mitigation of this situation can come from a fundamental reliance on visualization (harmonization of logical-verbal and visual thinking) in the preparation and presentation of educational material. It is also very important to convey to students that we are beginning to live in a visual turn, and the experience of educational online work is the essence of preparation for the new realities of modern culture and, accordingly, future professional activities.

Distance learning technologies consist of distance learning pedagogical and information technologies. Distance learning pedagogical technologies are technologies of mediated active communication between teachers and students using telecommunications and the methodology of individual work of students with structured educational material presented in electronic form. Information technologies for distance learning are technologies for creating, transferring and storing educational materials, organizing and supporting the educational process of distance learning through telecommunications. 
Today, there are several distance learning technologies, the purpose of which is to provide education applicants with access to electronic resources through the use of modern information technologies and telecommunication networks. Distance learning technologies in higher education open up opportunities to influence the solution of problems in the training of specialists:

- improving the quality of education in the higher educational institutions;

- formation of a unified educational space within the framework of higher education;

- meeting the needs of future specialists in educational services;

- increasing professional mobility and activity of future specialists;

- individualization of education in the case of mass higher education.

Distance learning technologies include an individual process of transferring and assimilating knowledge, skills, and cognitive skills of future specialists. They can be seen as a process of evolution of traditional education from a blackboard with chalk to a multimedia board and computer learning systems, from an ordinary book library to an electronic one, from a classroom to a virtual one. In addition, they enable online learning; to diversify the communication between students and teachers (e-mail, chat, forum, social networks, etc.); activate the role of the teacher and monitor the educational process; apply testing of different levels of complexity; replenish the database, accumulate statistics of different levels, etc.

Of course, distance learning has a number of positive aspects compared to traditional forms of education, namely (Bansak, Starr, 2021):

- availability of training and all training materials;

- mobility;

- the opportunity to study according to an individual schedule;

- the ability to study anywhere;

- learning in a relaxed atmosphere;

- the opportunity to study in several areas without interrupting professional activities;

- application of information and communication teaching aids to create a high-quality educational environment;

-development and expansion of computer literacy skills;

- creation and customization of distance courses, taking into account the needs and characteristics of students;

- advanced training, with the help of online courses and webinars (foreign and domestic);

- convenience for the teacher.

The use of distance technologies in the learning process allows students to choose a convenient time for studying and mastering educational courses, independently monitor and analyze their educational activities, and teachers - to manage the educational work of students, monitor and analyze their activities, which stimulates the student to conscientiously master the content of higher education. Students can study without leaving home or being in any other place, in order to start learning, you need to have a phone, tablet or computer with access to the Internet. The absence of the need to visit an educational institution every day is a big plus for people with health problems and disabilities, for those who live in remote areas, for mothers on maternity leave or with small children. The use of distance technologies is also suitable for teachers for organizing an individual approach to teaching and operational work with students (Sukhodimtseva, Sergeeva, Lukashenko, Pyankov, 2021).

At the same time, distance learning has a number of disadvantages (Table 1.) 
Table 1. The main disadvantages of using distance education methods for teaching students (future biology teachers).

\begin{tabular}{cc}
\hline № & Disadvantage \\
\hline 1 & insufficient development of practical skills and abilities \\
2 & low level of sociability \\
3 & network coverage problems \\
4 & providing technical means of communication \\
5 & financial and energy costs \\
6 & complexity of control over the independence of tasks \\
7 & loss of motivation for learning and control \\
8 & student identification \\
\hline
\end{tabular}

The distance student studies and masters almost all the educational material on his own, which requires a certain willpower, responsibility and self-control, because no one will adjust or encourage him, therefore, not everyone succeeds in maintaining the required pace of learning without outside control.

The correct organization of distance learning is a necessary thing not only during the period of quarantine restrictions. However, in the era of technologies that are practically accessible to everyone and fit into a smartphone, organizing the educational process is not an easy task. The organization of training future subject teachers by means of distance technologies is a useful experience for successful further professional activities. The main purpose of using distance learning is to provide access to electronic educational resources through the use of modern information technologies and telecommunication networks.

Distance learning technologies include the ability to work with electronic textbooks, e-mail, work with distance platforms, courses, communication through forums, chats, conferences and webinars. The most popular are new, interesting, relevant distance courses Prometheus, TeachHub, EdEra, World Education, which are focused on obtaining theoretical knowledge and practical skills in a short time.

The Moodle system is quite widespread, which perfectly copes with the tasks facing distance learning and gives users the following benefits (Lukyanova, 2020):

- free platform that can be downloaded, installed and modified freely;

- allows to create and manage courses;

- allows to create tests of different levels;

- includes various educational elements (for example, a magazine);

- allows to implement differentiated learning;

- allows communication;

- Allows the publication of educational content in different formats: audio, video, text and others.

The Google Classroom platform provides an opportunity to:

- create your own course and organize the enrollment of students for the course;

- share the necessary teaching material;

- propose tasks;

- evaluate the performance of tasks and monitor their progress;

- organize communication.

Zoom video conferencing application is distributed, one of the most famous and popular applications, which is great for both teachers and students. The use of this application gives users the following benefits (Christensen, Anakwe, Kessler, 2001):

- number of participants up to 100 people;

- free conference duration up to 40 minutes; 
- the ability to share the screen;

- the ability to record;

- the possibility of communication.

The Padlet platform, designed for distributing tasks, allows you to write instructions, add links, photos, videos, any other file, drawing, screenshot, voice message, or even geolocation. Prezzi and Canva make presentations good and interesting. Kahoot and Quizlet are gamified learning platforms that allow you to create interactive quizzes, quizzes, practice assignments, and test material.

Many educational platforms for studying individual disciplines with ready-to-use teaching material. For example, 24 Easy Steps - a platform for learning English, Matific for learning mathematics, Bchy.com.ua History, Osvita.ua for studying the history of, Subject - for studying biology, Vsem.pptx - for studying computer science. Mozaik is a platform for teaching basic school disciplines that contains 3-D presentations and photographs, videos, audio and photographic materials, presentations, ready-made digital lessons, games and much more.

Using the Explain Everything and Lino online whiteboards in class will help engage the entire class on an engaging educational journey, and the advanced features of these boards will allow you to track the depth of understanding of the topic. Useful enough in GoLab / Graasp online lab classes, online simulations, Liveworksheets interactive worksheets, Wizer.me and other tools to help solve learning problems and improve the learning process for distance and blended learning.

The indicated techno trends influence an increase in motivation for educational activity, provide opportunities for the use of new forms in the educational process, in which students will learn not only to assimilate knowledge, but also to acquire it independently, to use the acquired knowledge during the educational process and in everyday activities.

Students - future teachers of biology, in the learning process of whom distance technologies are used, receive double knowledge: firstly, they themselves study the material they need for their further professional activities, and secondly, they have the opportunity to see ways of presenting information using modern technologies that can be used in teaching. The organization of distance learning requires the formation of students in the learning process of the appropriate readiness to perform these new educational functions.

The pandemic has shown that distance education can well compete with traditional education. Moreover, it has become a driver of a worldwide shift towards online learning. Despite the fact that distance education was not so popular until 2020, today's reality shows that this form of education is already a necessity.

Although no one can prematurely guarantee the consequences and results of online learning, there is no doubt that they will appear in the short term. Effective implementation of online learning requires a large amount of time and resources, as well as support from key stakeholders interested in the development of quality online education.

Consequently, higher education institutions that train biology teachers will have to cope with the following primary tasks in the current situations (Casarotti, Filliponi, Pieti, Sartori, 2002):

- Developing the strategic planning of the institution, taking into account the attendant risks to predict the short- and long-term consequences of the pandemic and the expected economic downturn.

- Development of a support system for students and teachers: providing students with the necessary equipment, organizing trainings and training seminars within the framework of online education, creating a platform for exchanging experiences, methodological support in adapting programs to forms of online education.

- Changing the procedures and criteria for assessing knowledge in accordance with the new teaching format and pedagogical approaches. 
- Close cooperation with other universities of national and international level to exchange experience and resources.

The criteria for the quality of distance learning for future biology students are assessed through such indicators as the positive impact of the educational process on increasing the level of education of the individual and creating the most comfortable living conditions for him, improving all aspects of social relations, and forming an open democratic society. An increase in the level of education gives a person important advantages: improved working conditions, the opportunity to occupy a higher position, more varied and meaningful rest, increased opportunities for the physical and mental development of children. The above concerns the effectiveness of education in general, regardless of the form of its receipt. The effectiveness of distance learning is associated with the achievement of educational and educational goals that modern society and new socio-economic conditions set for higher education.

Thus, the effectiveness of distance education for students-future biologists shows the degree of compliance of the results obtained with the set tasks of the educational process in the person of a trained graduate of the distance education system with the least expenditure of time, labor, health of teachers and students, money (both on the part of the student and by the provider of educational services remotely). Typically, the criteria for the quality of distance learning are (Bakhov, Ryzhykov, Kolisnyk, 2018):

1) assessment of knowledge of academic disciplines;

2) the level of systemic competence (the ability to correct and improve working systems, the ability to monitor and correct activities, understanding the relationship between social, organic and technical systems);

3 ) the level of competence in the allocation of resources (the ability to allocate time, the ability to allocate money and materials, the ability to allocate space, the ability to allocate personnel);

4) the level of technological competence (the ability to choose equipment and tools for solving a given problem, the ability to carry out their technical care and diagnostics, the ability to apply technology to perform specific tasks);

5) the level of competence in working with information (the ability to acquire and evaluate knowledge, the ability to effectively interpret and transmit information, the ability to professionally use computer systems);

6) assessment of basic skills (writing, reading, speaking, listening);

7) assessment of personal qualities (personal responsibility, self-government, communication skills, self-respect);

8) assessment of mental skills (the ability to think creatively, the ability to make decisions, the ability to foresee, the ability to learn);

9) assessment of interpersonal skills (the ability to work in a team, the ability to teach others, the ability to negotiate, leadership qualities). The analysis of quality criteria proves that the education of a specialist and the quality of his training in the distance education system is growing significantly.

Studies of the practical activities of educational institutions that provide educational services remotely made it possible to identify factors that affect the efficiency of teachers and students as key elements in the system of distance education. They directly and indirectly affect the quality of distance learning. These factors largely coincide with the factors determining the influence of technical teaching aids in traditional teaching (Cinar, Torenli, 2010):

1. Factors of the labor process (goal, objectives, the complexity of the learning content to be mastered). The more complex they are, the more requirements are imposed on the capabilities of its performers (physical, mental), the technical equipment of the learning process and its external 
conditions. These factors determine the load (type, intensity of time distribution) and the stages of training.

2. Organizational and managerial factors or factors of the material and technical equipment of the teacher and student (including the availability of the necessary equipment, technical means, organization of the workplace, ensuring the use of progressive methods and organizational forms of work, the rationality of modern information technologies, characterizing the correspondence of the complex of material resources to the goals and learning objectives, the content of the program, the characteristics of the teacher's labor activity and the cognitive abilities of students, the adaptability of modern information technology tools to organizational forms, methods and techniques of teaching.

3. Factors of the external environment (regulatory, sanitary and hygienic, aesthetic, technical).

4. Human factors - factors of the social environment (worldview, attitude to one's profession, degree of responsibility, level of professionalism, motivational attitudes, communication skills, etc.) interest in the results of the work).

5. Factors due to individual characteristics of a person: psychophysiological, anthropometric, behavioral characteristics; natural qualities - learning ability, health, age, etc. They affect the time spent by the teacher on the transfer of educational information and the time spent by students on its perception, as well as on the preparation of modern information technology.

\section{CONCLUSION}

The pandemic has forced the global academic community to recognize distance and online learning as the main form of education. All teachers and university students from around the world were forced to overcome difficulties in a relatively new direction for them, while helping to combat the spread of the virus. This study demonstrates how Kazakhstani universities have adapted to the new form of education and what difficulties they encountered in the implementation of training.

During the pandemic, distance education platforms have become a key tool in the implementation of the educational process. As the results show, the country's universities before the pandemic actively used platforms such as Platonus and Moodle, and during the pandemic, some developed their own platforms, while others used such well-known platforms as ZOOM, Microsoft Teams, Webex Cisco and others.

Consequently, in the modern system of organizing pedagogical training in higher educational institutions, the use of distance learning technologies is an integral part of ensuring high-quality education, the use of which reveals the possibilities of a positive impact on improving the quality of education, ensures the fulfillment of the needs of future biology teachers in educational services, and increases professional mobility. and activity. Technologies contribute to the formation of a single educational space within the framework of the individualization of education in the case of mass higher education. The development of technologies in the modern world has led to a revision of traditional approaches to the definition of promising forms of organizing the educational process. The continuous increase in the amount of information prompts the need to improve the training of teachers, the search for innovative technologies for advanced training, as well as constant, continuous improvement of the professional competence of specialists.

Authors' Contributions: Biletska, H.: conception and design, acquisition of data, analysis and interpretation of data, drafting the article, critical review of important intellectual content; Mironova, N.: conception and design, acquisition of data, analysis and interpretation of data, drafting the article, critical review of important intellectual content; Kazanishena, N.: conception and design, acquisition of data, analysis and interpretation of data, drafting the article, critical review of important intellectual content; Skrypnyk, S.: conception and design, acquisition of data, analysis and interpretation of data, drafting the article, critical review of important intellectual content. All authors have read and approved the final version of the manuscript. 
Ethics Approval: Not applicable.

Acknowledgments: Not applicable.

\section{REFERENCES}

Harunasari, S. Y., \& Halim, N. (2019). Digital Backchannel: Promoting Students' Engagement in EFL Large Class. International Journal of Emerging Technologies in Learning (iJET), 14(07): 163-178.

https://doi.org/10.3991/ijet.v14i07.9128

Kassabolat, A., Kadirsizova, S., Kozybayeva, M., Kalkeyeva, K., Zhorokpayeva, M., \& Aknur, Y. (2020). Future Teachers' Opinions on Preparation and Use of Interactive Materials in Teaching. iJET, 15, 121-130.

Fedorov, A. A., Mialkina, E. V., Sedykh, E. P. S., \& Zhitkova, V. A. (2021). Model of managing the professionaleducational route of a future specialist. Revista Tempos E Espaços Em Educação, 14(33), e16325. https://doi.org/10.20952/revtee.v14i33.16325

Sukhodimtseva, A., Sergeeva, M., Lukashenko, D., \& Pyankov, M. (2021). The methodology of the creation of a flowchart of teacher professional development programme in functional literacy aspect. Revista Tempos E Espaços Em Educação, 14(33), e15525. https://doi.org/10.20952/revtee.v14i33.15525

Awe, O.A. And Church, E.M. (2020), "Project flexibility and creativity: the moderating role of training utility", Management Decision, Vol. ahead-of-print No. ahead-of-print. https://doi.org/10.1108/MD-02-2020-0226

Beyth-Marom, R., Chajut, E., Roccas, S. \& Sagiv, L. (2003) Internet-assisted versus traditional distance learning environments: factors affecting students' preferences, Compiters \& Education, 41, p. 65-76.

Casarotti, M., Filliponi, L., Pieti, L. \& Sartori, R. (2002) Educational interaction in distance learning: Analysis of one-way video and two-way audio system. PsychNology Journal, 1(1), 28-38.

Christensen, E. W., Anakwe, U. P. \& Kessler E. H. (2001) Receptivity to distance learning: the effect of technology, reputation, constraints, and learning preferences. Journal of Research on Computing in Education, 33 (3), $263-79$.

Cinar, M \& Torenli, N. (2010) Redesign online courses with students' expectations: a case study with a new infrastructure, Social and Behavioural Science, 9, p. 2013-2016.

Bakhov, I., Ryzhykov, V. And Kolisnyk, O. (2018). Leadership Abilities of a Military Manager, Professionalism of a Commander as the Guarantee of the Practice of Effective Activity of a Military Organization. International Journal of Engineering \& Technology, 7(4.38), 45-49. https://doi.org/10.14419/ijet.v7i4.38.24318

Bansak, C. \& Starr, M. (2021). Covid-19 shocks to education supply: how 200,000 U.S. households dealt with the sudden shift to distance learning. Review of Economics of the Household. https://doi.org/10.1007/s11150-020-09540$\underline{9}$

Lukyanova, L. B. (2020). Andragogical experience in the organization of vocational training in industry Modern information technologies and innovative teaching methods in training specialists: methodology, theory, experience, problems, 1 (29), 86-90.

Received: 31 August 2022 | Accepted: 12 December 2021 | Published: 14 January 2022 